\section{ambient \\ SCIENCE \\ Vol. 04(2): 42-43 \\ Year 2017}

NOTES ON NATURAL HISTORY

\title{
Bildwar Gufa: a Derelict Cave on the Way of Natural Rehabilitation Centre for Microchiropteran (Bats)
}

\author{
Siddharth Biswas ${ }^{1,2 *}$, Amit Singh Banafar ${ }^{3}$ \\ ${ }^{1}$ National Cave Research and Protection Organization, Central \\ Laboratory, Raipur, 492001, C.G., India \\ ${ }^{2}$ School of Earth science, Department of Environmental Science, \\ Central University of Rajasthan, Dist. Ajmer, Rajasthan, \\ India \\ ${ }^{3}$ Government College Silf ili, District Surajpur, Chhattisgarh,
}

\section{Introduction:}

Both animals and humans are the part of this universe and possess equal right to coexist. However, due to more intelligence human succeeded to rule over the universe, restricting animals in habitats which they felt safe from human hands. Each animal has some role in our ecosystem but unfortunately, we the human beings reserve the divine right with us to select their (animals) survival. Alas, today we are realizing that due to such arrogant behaviour we have lost many such animals either completely or partially from the whole universe or from some specific part of our ecosystem whose existence would have been beneficial for us in the present scenario.

From the ancient age, in Asian countries, we always grabbed natural habitats (caves) of the microchiropteran bats and converted them into our worship/meditation places (temples/monastery). In return, bats are compelled to occupy either our abandoned and derelict buildings or mines for their day roosting purposes. However, till date, no such report is available which support the faunal natural rehabilitation in any abandoned / derelict natural cave which was once used by human beings for their recreational/religious purpose.

In the present note, we are presenting a report on processing natural wildlife rehabilitation in a small partially collapsed derelict cave which had served as a temple forvarious decades..

\section{Bildwargufa:}

Bildwar gufa (cave) is a small half circular shaped subterranean passage formed in coal cum sedimentary rock formation. It is located in an unreserved forest area which is on Pratappur road, district Surajpur, Chhattisgarh, India. The area is surrounded by South Eastern Coalfields Limited's (SECL) coal mines and just a few $\mathrm{km}$ apart from this cave a big coal mine is under operation where the serial blasts are a regular phenomenon. Since last various decades, this cave was
Study Area: Surajpur, Chhattisgarh, India

Coordination: $23^{\circ} 19^{\prime} 14.3^{\prime \prime} \mathrm{N} 83^{\circ} 12^{\prime} 15.1{ }^{\prime \prime} \mathrm{E}$

Key words: Abondand, Prey, Predator, Cats.

serving as a local pilgrim spot which gradually developed into religious picnic spot by constructing several civil recreational structures around it to attract people (Fig.-1).

Unfortunately, in the year 2014, February, a part of this cave collapsed and 8 people died who were trapped inside at that moment. Following this tragic event government declared this cave as abandoned and the main entrance of it was closed by constructing a concrete wall. In the present scenario, the venue which was always had a throng of people is left in a derelict condition.

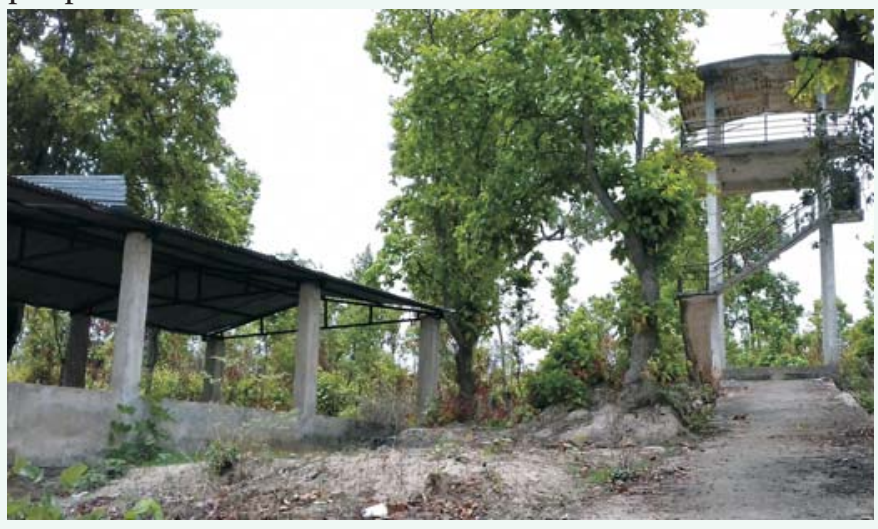

Figure-1: Outer ambient view of Bildwar gufa which was developed into a picnic spot to attract the tourists

\section{Ourobservations:}

Since the beginning of this year (2017), we have made few trips to this derelict (abandoned) cave to tabulate the rehabilitated biodiversity (if any). All the civil structures once constructed inside it to facilitate the pilgrims/ tourists movement in this cave are lying intact. Continuous seepage from the various side walls of this cave forms a small stream coming out from it. Surprisingly, we didn't find any major arthropod; like cricket, spider, millipede, etc. inside this derelict cave which is otherwise commonly found in any cave or grotto. While serving as a pilgrim spot, the highly smoky conditions maintained since last various decades, possibly altered the inner

*Corresponding Author: sid@caves.res.in 
atmosphere of Bildwar cave to such an extent that till date i.e., after completion of 3 years in derelict conditions it has not become favourable to harbour the invertebrates.

Interestingly in the present scenario, this derelict cave has been occupied by a small group of microchiropteran, Rhinolophus sp. (horseshoe bat). This bat roosts during the daytime in the innermost chamber of the cave, the distance of which is about $50 \mathrm{~m}$ from the present entrance. However, when there is prey the existence of the predators could not be ruled out. During our visits, we found dense pugmarks of civet (possibly Viverricula indica) throughout the range of the cave. Some pugmarks of any big animals were also noticed but at this stage, we are not in the position to identify them (Fig.-2). Several reports suggest that the civet visit the caves to predate roosting bats (Harries et al., 2009; Biswas \& Shrotriya, 2011). Possibly the various constructed civil structures inside the cave facilitate the civet and other carnivores to hunt microchiropteran bats easily here (Fig.-3). Further, the domestic cats are also reported to hunt bats (Ancillotto et al., 2013; Virkar \& Shrotriya, 2013), thus from the possibility of also entering the domestic cats as predators could not be denied.

For the first time, our survey is reporting on natural faunal rehabilitation for any derelict cave which was earlier serving as human recreation centre for several decades. We found that mammals are the only such type of fauna which occupies any available uninhabited space in first come first serve basis.

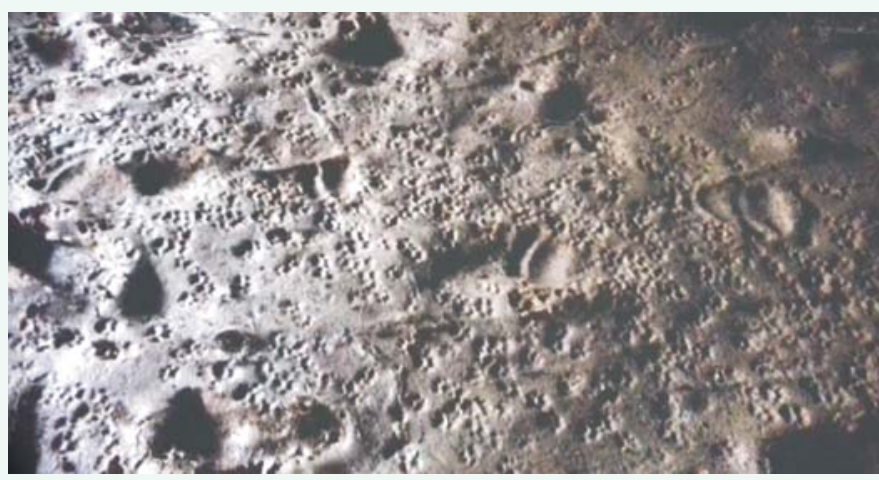

Figure-2: Pugmarks of the carnivores scattered throughout the range of the cave.

\section{Future direction:}

Microchiropterans uses caves/any subterranean hollow passage for its various biological means viz., night roosts, mating, hibernating, maternity (pre-birthing, birthing, pre-weaning, weaning, postweaning) etc. Such selections dramatically vary depending on habitat meets the requirements. With developing day-by-day the human encroachment to the caves the poor cave-roosting bats are losing their habitat which ultimately raises the question of their existence. Various microchiropteran bats have been seen to occupy the derelict mines but there also its existence is usually checked while the entrances of such

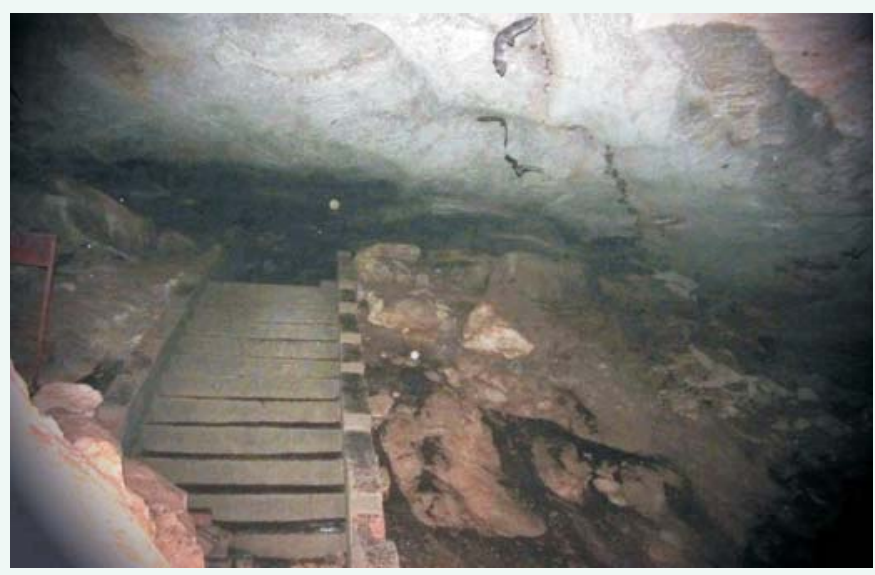

Figure-3: Inner view of the Derelict cave occupied by a small bat population

mines are packed to reduce the hazards for the civil community. Thus, it is advisable to use every derelict subterranean passages either cave, grotto or mines as natural rehabilitation zone for microchiropteran bats and the entrance must be closed to check the possible predation and also unusual anthropogenic activities by specially designed gates (Sherwin et al., 2009; King, 2005; Tuttle \& Taylor, 1998; MCMPR \& MCA, 2010).

Acknowledgements:

This work has been supported by Chhattisgarh Council of Science and Technology, Raipur Chhattisgarh under the MRP Scheme (1942/CCOST/MRP/14). Thanks are also due for "IDEA WILD" (www.ideawild.org) for providing us a camera lens to use in work related to cave roosting bat's conservational issues.

\section{References:}

Ancillotto, L., Serangeli, M.T. \& Russo, D. (2013): Curiosity killed the bat: Domestic cats as bat predators. Mamm. Biol., 78(5):369-373.

Biswas, J. \& Shrotriya, S. (2011): Dandak: the mammalian dominated cave ecosystem of India. Int. J. Subterranean Biol., 40:1-7.

Harries, D.B., Ware, F.J., Fischer, C.W., Biswas, J. \& Khapran-Daly, B.D. (2008): A Review of the Biospeleology of Meghalaya, India. J. Cave Karst Stud., 70(3),163-176.

King, R.H. (2005): Microclimate effects from closing abandoned mines with culvert bat gates. Technical Note 416. U.S. Pub. by: Department of the Interior, Bureau of Land Management, Colorado State Office, Denver, CO. BLM/CO/ST-04/oo6+REVo5. P-13.

MCMPR \& MCA (2010). Strategic Framework for Managing Abandoned Mines in the Minerals Industry. Pub. By: Ministerial Council on Mineral and Petroleum Resources (MCMPR) and the Minerals Council of Australia (MCA). P.44.

Sherwin, R.E., Altenbach, J.S. \& Waldien, D.L. (2009): Managing Abandoned Mines for Bats. Pub. By: Bat Conservation International, Inc. Printed in the U.S.A., P. 107.

Tuttle, M.D. \& Taylor, D.A.R. (1998): Bats and Mines: Resource Publication No.-3. Pub. By: Bat Conservation International, Inc.P-50.

Virkar, P.S. \& Shrotriya, S. (2013): Threat to wildlife from carnivorous pets: A case of cat attacking Indian Pipistrelle Pipistrellus coromandra (Gray, 1838). Zoo's Print, 28(8):25-27. 